\title{
PEMBINAAN UNTUK PRODUK KOPI HALAL PADA KELOMPOK TANI PANGESTU RAKYAT DESA BARU MANIS KABUPATEN REJANG LEBONG
}

\author{
Ghufira, Irfan Gustian, Asdim \\ Jurusan Kimia, Fakultas Matematika dan Ilmu Pengetahuan Alam \\ Universitas Bengkulu \\ Email : ghufira@gmail.com
}

\begin{abstract}
ABSTRAK
Kabupaten Rejang Lebong Provinsi Bengkulu merupakan kabupaten dengan jumlah kebun kopi yang cukup luas. Salah satu kelompok tani yang bertanam kopi dikebunnya adalah Kelompok Tani Pangestu Rakyat yang tepatnya berlokasi di Desa Baru Manis Kecamatan Bermani Ulu Kabupaten Rejang Lebong. Selain berkebun kelompok tani ini mengolah kopi hasil panen mereka untuk dijadikan bubuk kopi dan dijual ke daerah sekitarnya. Saat ini produk kopi bubuk dari Kelompok Tani Pangestu Rakyat ini belum mempunyai sertifikat halal. Kelompok tani ini sadar betul mengenai kehalalan suatu produk akan memberikan nilai tambah bagi produknya, karena konsumen dari produk kopi mereka sebagian besar adalah masyarakat muslim. Namun sampai saat ini Kelompok Tani Pangestu Rakyat belum mengetahui proses apa yang harus dilakukan agar produknya bisa disebut sebagai produk halal dan bisa mendapatkan sertifikat halal. Kegiatan pengabdian kepada masyarakat ini dapat membantu memecahkan permasalahan yang dihadapi. Melalui kegiatan ini Kelompok Tani Pangestu Rakyat diberikan pengetahuan dan pembinaan berupa materi mengenai produk halal, proses untuk mencapai suatu produk halal, dan alur yang harus dilalui untuk memperoleh sertifikat halal untuk suatu produk. Kegiatan ini sejalan dengan program pemerintah yang sudah dituangkan dalam Undang-undang no. 33 tahun 2014 mengenai jaminan produk halal. Undang-undang tersebut menyatakan bahwa semua produk yang beredar di Indonesia wajib memiliki sertifikat halal.
\end{abstract}

Kata Kunci : Kelompok tani, produk kopi, produk halal, sertifikasi halal

\section{PENDAHULUAN}

$\begin{array}{lrr}\begin{array}{l}\text { Indonesia } \\ \text { dengan }\end{array} & \begin{array}{r}87 \\ \text { adalah }\end{array} & \text { muslim, } \\ \text { menduduknya } & \text { aduan pasar yang } & \text { besar bagi } \\ \text { produk halal. Untuk } & \text { itu sudah } \\ \text { selayaknya pemerintah } & \text { menyediakan } \\ \text { produk yang terjamin } & \text { kehalalannya } \\ \text { sehingga } & \text { dapat } & \text { memberikan } \\ \text { kenyamanan dan ketentraman bagi } \\ \text { masyarakatnya terutama masyarakat }\end{array}$

muslim (Warto dan Syamsuri, 2020). Pemerintah sudah menetapkan Undangundang no 33 tahun 2014 (UUJPH) tentang jaminan produk halal yang menyatakan bahwa semua produk yang beredar di Indonesia wajib memiliki sertifikat halal. Produk yang wajib memiliki sertifikat halal itu sendiri adalah produk yang telah dinyatakan halal sesuai dengan syariat Islam. 
Produk yang dimaksudkan adalah makanan, minuman, obat, produk kimiawi dan biologi, produk rekayasa genetik, kosmetik dan barang gunaan serta jasa seperti sektor pariwisata (Anonim, 2020)(MUI.org).

Suatu produk dapat dikatakan halal harus melalui proses. Proses produk halal didefinisikan sebagai rangkaian kegiatan untuk menjamin kehalalan produk mencakup penyediaan bahan, pengolahan, penyimpanan, pengemasan, pendistribusian, penjualan, dan penyajian produk. Hal ini bertujuan memberikan kenyamanan, keamanan, keselamatan, dan kepastian ketersediaan produk halal bagi masyarakat dalam mengonsumsi dan menggunakan produk serta meningkatkan nilai tambah bagi pelaku usaha untuk memproduksi dan menjual produknya (Charity, 2017).

Selaras dengan hal ini maka setiap produk yang diperdagangkan di Indonesia baik produksi skala kecil atau besar wajib memiliki sertifikat halal. Adanya sertifikat halal pada produk dapat memberikan jaminan kepada masyarakat bahwa produk yang dijual tersebut layak dikonsumsi dan digunakan oleh masyarakat muslim. Pemberlakuan undang-undang ini dimulai pada 17 Oktober 2019, dan diperkuat oleh Peraturan Pemerintah no. 31 tahun 2019 yang menyatakan bahwa penetapan sertifikasi halal dilaksanakan secara bertahap, dan tahap awal diberlakukan untuk produk makanan dan minuman (PP no. 31, 2019).

Kelompok tani dapat dikatakan merupakan bagian dari Usaha Menengah dan Kecil Menengah (UMKM). Dalam tujuan strategis tahun 2015-2019, Kementerian Koperasi dan UKM salah satunya dinyatakan bahwa meningkatnya kontribusi koperasi dan UMKM dalam perekonomian melalui pengembangan komoditas berbasis koperasi/sentra di sector-sektor unggulan, dan meningkatnya wirausaha baru dengan usaha yang layak dan berkelanjutan (Huda dan Nazirwan, 2018). Kelompok Tani Pangestu Rakyat merupakan salah satu kelompok tani yang berada di Kabupaten Rejang Lebong Provinsi Bengkulu. Dilihat dari kegiatan kelompok tani ini, maka dapat dikategorikan sebagai UMKM yang dapat membantu terwujudnya tujuan dari Kementerian Koperasi dan UKM tersebut. Kelompok tani Pangestu Rakyat merupakan petani dibidang tanaman hortikultura terutama kopi (Triawan dkk, 2021). Kopi hasil panen biasanya dijual ke penampung atau 
toke. Namun beberapa anggota kelompok tani ini sudah mencoba memutus rantai tersebut dengan memproduksi bubuk kopi dari hasil panennya sehingga dapat dijual ke masyarakat. Cara ini dapat membantu kelompok tani tersebut untuk meningkatkan pendapatan anggota kelompoknya. Permasalahan yang dihadapi saat ini oleh Kelompok Tani Pangestu Rakyat adalah produk bubuk kopi yang dibuat oleh kelompok tani ini belum mempunyai sertifikat halal. Kelompok tani mengetahui kehalalan suatu produk akan memberikan nilai tambah bagi produknya, karena konsumen dari produk kopi mereka sebagian besar adalah masyarakat muslim. Namun sampai saat ini Kelompok Tani Pangestu Rakyat belum mengetahui proses apa yang harus dilakukan agar produknya dapat disebut sebagai produk halal dan bagaimana proses mendapatkan sertifikat halal.

Kegiatan ini membantu memecahkan permasalahan yang dihadapi oleh Kelompok Tani Pangestu Rakyat. Melalui kegiatan pengabdian ini kelompok Tani Pangestu Rakyat diharapkan dapat meningkatkan pengetahuan mereka mengenai proses produksi bubuk kopi yang baik, sehat dan halal sehingga produknya layak untuk diajukan sertifikasi halalnya.

\section{METODE PELAKSANAAN}

Metoda yang digunakan untuk mencapai tujuan kegiatan pengabdian pada masyarakat Kelompok Tani Pangestu Rakyat Desa Baru Manis Kecamatan Bermani Ulu Kabupaten Rejang Lebong, dapat dilakukan dengan langkah sebagai berikut :

1. Kuisioner awal, bertujuan untuk mengetahui tingkat pemahaman anggota kelompok tani mengenai produk halal.

2. Penyampaian informasi, dilakukan setelah mengetahui hasil kuisioner awal. Penyampaian materi dalam bentuk ceramah dan diskusi. Peserta kegiatan pengabdian diberikan materi tentang produk halal, undang-undang penerapan sertifikasi halal dan alur pengajuan sertifikasi halal.

3. Kuisioner akhir, diberikan pada sesi akhir untuk melihat peningkatan terserapnya materi oleh peserta.

4. Pembinaan dilakukan agar peserta benar-benar memahami dan bisa mengimplementasikan pada proses pembuatan produk kopi agar 
produk layak disebut sebagai produk halal.

\section{HASIL DAN PEMBAHASAN}

Kegiatan pengabdian pembinaan terhadap masyarakat kelompok tani Pangestu Rakyat yang berada di Desa Baru Manis Kabupaten Rejang Lebong Provinsi Bengkulu telah dilaksanakan dan berjalan lancar. Pada tahap awal kegiatan setiap anggota kelompok tani diberikan kuisioner yang berisi tentang pengetahuan masyarakat tentang produk halal, undang-undang mengenai jaminan produk halal, dan pengetahuan lain terkait kehalalan suatu produk serta bentuk logo halal yang resmi suatu produk. Pada tahap ini dapat dilihat bagaimana pengetahuan masyarakat terutama anggota kelompok tani Pangestu Rakyat terhadap produk halal. Menurut Kardoyo, dkk (2018), indicator keberhasilan pelaksanaan pengabdian diukur dari tingkat keterampilan dan pemahaman peserta terkait bidangnya sebesar lebih dari $60 \%$.

Dalam kuisioner yang diberikan salah satu pertanyaannya adalah mengenai pengetahuan masyarakat terhadap Undang-undang no. 33 tahun 2014 mengenai jaminan produk halal dan produk halal itu sendiri.
Berdasarkan isian kuisioner tersebut didapatkan informasi bahwa seluruh (100 \%) anggota kelompok tani tidak mengetahui tentang Undang-undang no. 33 tahun 2014 ini. Masyarakat kelompok tani belum pernah mendapatkan sosialisasi tentang Undang-undang no. 33 tahun 2014, baik dari media massa, media sosial maupun dari aparat desa. Pengetahuan anggota kelompok tani terhadap produk halal juga terbatas yaitu bahwa suatu produk dikatakan halal bila tidak mengandung najis dan mengandung bahan yang berasal dari hewan babi. Akan tetapi semua masyarakat kelompok tani mengetahui dan sadar bahwa produk makanan dan minuman harus mencantumkan label halal pada kemasannya.

Berdasarkan kuisioner yang diberikan, sebanyak $100 \%$ masyarakat kelompok tani menganggap bahwa label halal boleh dicantumkan pada kemasan produk tanpa melalui proses sertifikasi halal. Hal ini tentu bertentangan dengan proses pengusulan sertifikasi halal yang telah berjalan selama ini.

Titik kritis dalam penentuan suatu produk adalah halal atau tidak sangatlah penting. Titik kritis dalam suatu produk halal adalah titik atau keadaan dimana 
produk tersebut dapat terkontaminasi oleh suatu bahan yang najis atau haram. Berdasarkan hasil kuisioner tersebut, seluruh (100\%) anggota kelompok tani tidak mengetahui apa yang dimaksud dengan titik kritis dalam produk halal. Oleh karena itu kelompok tani diberikan edukasi mengenai titik kritis terutama untuk proses pembuatan bubuk kopi. Titik kritis dilihat mulai dari proses panen buah kopi, penjemuran buah kopi, pemilahan biji kopi, penyangraian sampai menjadi bubuk kopi. Bahkan tempat penyimpanan juga menjadi perhatian untuk melihat titik kritis dari produk kopi yang dihasilkan.

Beberapa anggota kelompok tani sudah mengolah kopi mereka secara mandiri. Sebanyak $85 \%$ anggota kelompok tani menganggap bahwa produk kopi yang diproses dan dikemas sendiri, dapat dijamin sebagai produk halal. Sebanyak $50 \%$ anggota kelompok tani berpendapat bahwa logo halal boleh dicantumkan pada kemasan produknya. Berdasarkan diskusi, diketahui bahwa anggota kelompok tani tidak pernah mendapatkan sosialisasi maupun edukasi mengenai aturan untuk pencamtuman logo halal tersebut. Namun anggota kelompok tani umumnya mengetahui bentuk logo atau label halal sehingga bisa dengan bebas menambahkan logo tersebut pada kemasan produknya.

Berdasarkan kuisioner awal yang diisi oleh anggota kelompok tani dapat diambil kesimpulan bahwa umumnya anggota kelompok tani Pangestu Rakyat dan masyarakat di Desa Baru Manis Rejang Lebong belum mempunyai pengetahuan yang baik mengenai produk halal. Kewajiban apa yang harus dilakukan agar produk kopi yang mereka hasilkan dapat disebut sebagai produk halal, dan dapat menjamin bahwa produk tersebut terjaga kehalalannya. Meskipun demikian sebanyak $57 \%$ dari anggota kelompok tani mengetahui syarat-syarat umum agar suatu produk bisa disebut sebagai produk halal. Maka dari hasil pada tahap awal ini dilanjutkan ke pemberian materi mengenai serba serbi produk halal dan memberikan informasi mengenai proses untuk memperoleh sertifikat halal.

Materi mengenai pengenalan produk halal dilakukan dengan metode ceramah dan diskusi. Metoda ceramah digunakan karena dianggap efektif untuk menyampaikan informasi mengenai suatu proses. Metoda ceramah adalah merupakan suatu cara 
yang digunakan untuk menerangkan atau menjelaskan suatu ide, pengertian, atau pesan secara lisan kepada kelompok sasaran (Notoatmojo, 2010). Sedangkan metode diskusi adalah metoda percakapan ilmiah yang responsif berisikan pertukaran pendapat yang dijalin dengan pertanyaan problematis, pemunculan ide atau pendapat yang dilakukan oleh beberapa orang yang tergabung dalam kelompok (Sagala, S. 2009). Gambar 1 memperlihatkan sesi pemberian materi melalui metode ceramah dan diskusi bersama anggota kelompok tani Pangestu Rakyat.

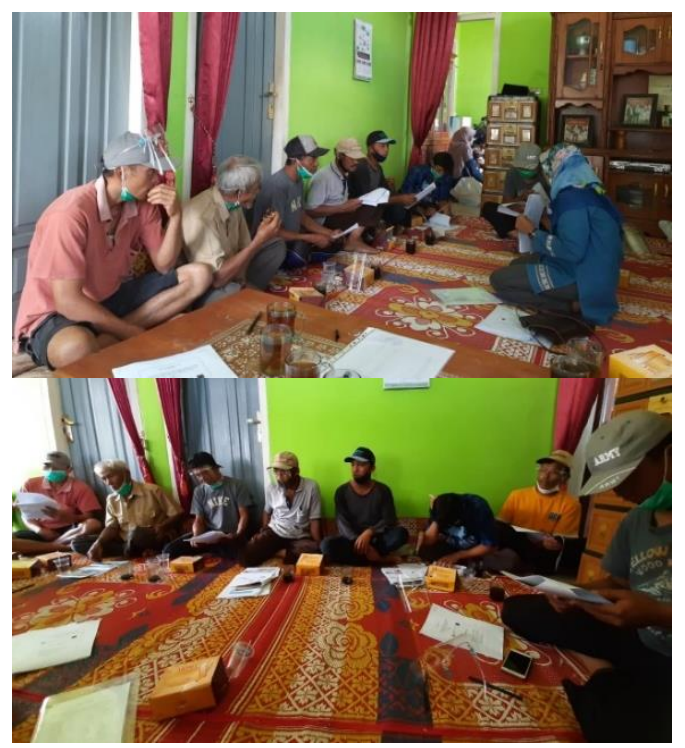

Gambar 1. Ceramah dan diskusi bersama kelompok tani

Sebagaimana telah diketahui bahwa sebagian anggota kelompok tani memproduksi bubuk kopi sendiri. Bubuk kopi ini kemudian dikemas dengan dibungkus plastik kemudian dipasarkan hanya di daerah sekitar Desa Baru Manis. Beberapa petani lain juga menjadi pemasok bubuk kopi ke penampung untuk dikemas ulang. Anggota kelompok tani dan masyarakat Desa Baru Manis umumnya tidak meragukan bahwa produk kopi yang mereka proses termasuk kepada produk halal. Namun selama sesi diskusi dan tinjauan di lapangan, masyarakat umumnya menjemur buah kopi di halaman dan tanah lapang yang bebas dilalui oleh hewan yang meninggalkan najis. Sehingga biji kopi yang sudah kering bisa dikatakan sudah terkena najis. Penjemuran dengan cara seperti ini merupakan salah satu titik kritis dari produk kopi yang akan dibuat oleh kelompok tani. Untuk mengantisipasi hal ini sebagian sebagian anggota kelampok tani sudah ada yang membuat tempat penjemuran khusus yang terjaga dari masuknya hewan terutama anjing. Gambar 2 memperlihatkan kopi dari kelompok tani yang dijemur di lapangan terbuka. Berdasarkan diskusi ini anggota kelompok tani mulai memahami apa yang dimaksud dengan titik kritis pada produk kopi mereka. 


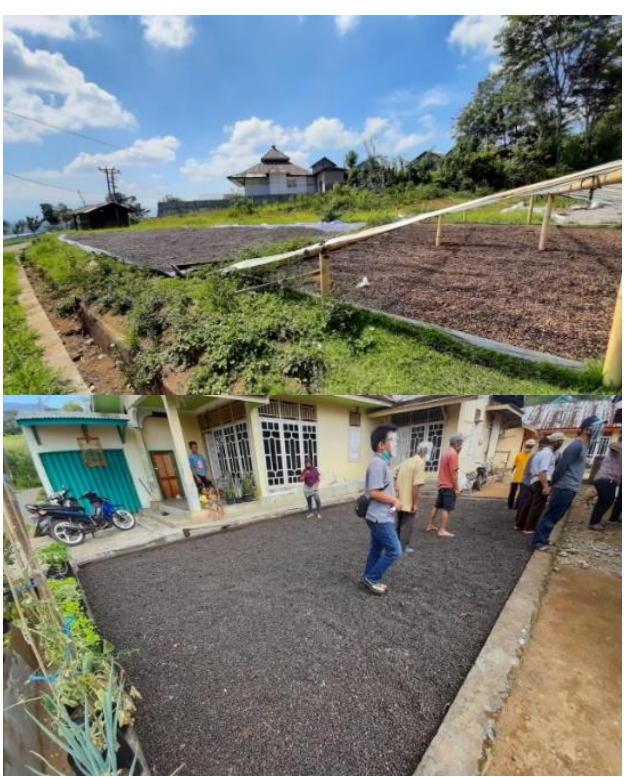

Gambar 2. Penjemuran buah kopi di lapangan terbuka

Suatu produk dapat dinyatakan halal terlebih dahulu harus melalui serangkaian proses yang terdiri dari penyediaan bahan-bahan baku pembuatan, pengolahan, penyimpanan, pengemasan, pendistribusian, penjualan, hingga penyajian. Semua proses yang dilalui ini harus terjaga dan terjamin kehalalannya, sehingga dapat diajukan untuk mendapatkan sertifikat halal. Pelaku usaha yang telah mendapatkan sertifikat halal sebaiknya mencantumkan label halal pada kemasan produknya dan ditempatkan di bagian yang mudah terlihat. Pelaku usaha yang tidak melakukan ketentuan tersebut, akan dikenakan sanksi berupa pencabutan sertifikat halal. (Anonim, pakaroti.com 2020).

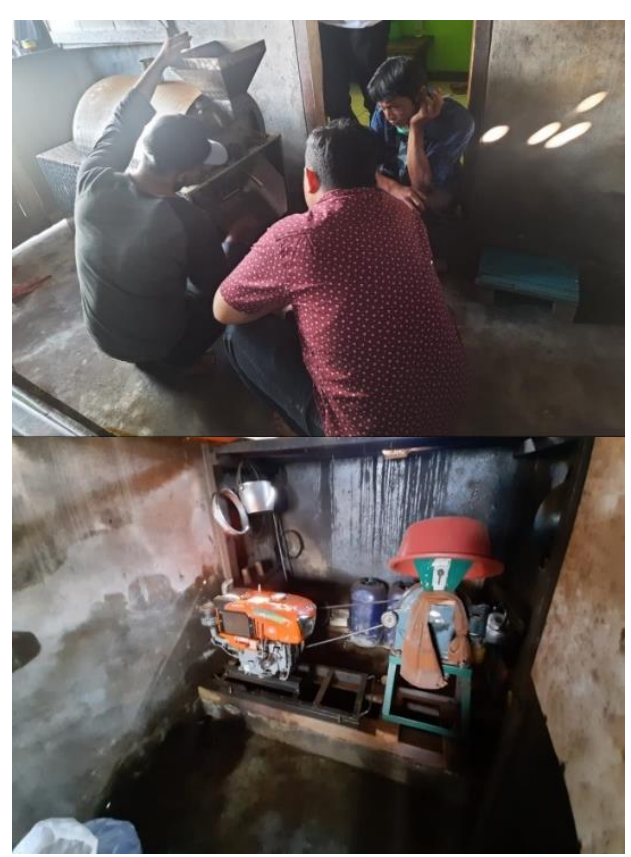

Gambar 3. Penggilingan biji kopi

Anggota kelompok tani Pangestu Rakyat tidak semuanya yang mengolah biji kopi menjadi bubuk kopi secara mandiri. Gambar 3 memperlihatkan tempat penggilingan biji kopi dan proses penggilingan biji kopi. Berbagai kendala dihadapi oleh kelompok tani ini. Beberapa kendala yang dihadapi oleh kelompok tani Pangestu Rakyat yaitu : 1. Anggota kelompok tani lebih memilih menjual biji kopi kering ke penampung (toke) karena mereka mendapatkan harga yang lebih stabil dibandingkan apabila mereka mengolah biji kopi menjadi bubuk kopi, yang apabila dijual keuntungan yang 
diperoleh sangat kecil, 2. untuk pengeringan biji kopi, umumnya anggota kelompok tani lebih memilih menjemur secara konvensional di lapangan terbuka karena untuk membuat tempat penjemuran yang tertutup membutuhkan biaya yang cukup besar, dan petani hanya mengandalkan perekonomiannya dari hasil kebun sehari-hari, dan 3. Anggota kelompok tani yang sudah mengolah bubuk kopi sendiri sampai saat ini belum mempunyai izin PIRT dari pemerintah. Sedangkan salah satu syarat utama untuk mengajukan sertifikasi halal adalah industri tersebut harus memiliki nomor izin PIRT. 4. Kendala lainnya adalah biaya untuk mengajukan sertifikasi halal yang cukup mahal bagi petani.

Pencantuman label halal sangat penting bagi produsen dan konsumen. Konsumen lebih merasa aman dalam mengkonsumsi produk atau makanan tersebut. Selain itu, konsumen juga mendapatkan jaminan bahwa produk tersebut tidak mengandung sesuatu yang tidak halal dan diproduksi dengan cara yang halal dan beretika. Sedangkan bagi produsen, pencantuman label halal dapat membangun kepercayaan dan loyalitas konsumen terhadap produk tersebut. Produk yang bersertifikat halal memiliki keunggulan kompetitif dibandingkan dengan produk yang tidak mencantumkan label tersebut.

Pada kegiatan ini disampaikan juga dokumen yang harus dilengkapi pada saat mengajukan sertifikasi halal. Dokumen tersebut adalah :

1. Data pelaku usaha, berupa surat izin usaha dari instansi berwenang.

2. Nama dan jenis produk harus sesuai dengan nama dan jenis produk yang akan disertifikasi.

3. Daftar produk dan bahan yang digunakan. Bahan yang digunakan baik bahan baku, bahan tambahan dan bahan penolong.

4. Proses pengolahan produk harus disampaikan secara terbuka, mulai dari penerimaan bahan baku, penyimpanan bahan baku, pengolahan bahan baku menjadi produk, pengemasan dan penyimpanan produk dan disertai dengan dokumen pendukung.

5. Hasil analisis dan/atau spesifikasi bahan (Halal.go.id, 2020)

Dalam proses sertifikasi halal harus melalui serangkaian pemeriksaan yang dilakukan oleh auditor bersertifikat yang kompeten dibidangnya. Apabila semua syarat sudah terpenuhi, maka 
pelaku usaha bisa mendapatkan sertifikat halal untuk produknya. Sertifikat ini digunakan sebagai syarat untuk memperoleh nomor registrasi dan pelaku usaha bisa mencamtumkan label halal pada produknya. Label ini merupakan bentuk jaminan pelaku usaha kepada konsumen bahwa produknya adalah produk halal (Faridah, 2019).

Kegiatan pengabdian ini dapat menunjang program pemerintah untuk meningkatkan jumlah sertifikasi halal terhadap produk yang beredar di Indonesia, dan diharapkan semua produk tersebut sudah tersertifikasi halal pada tahun 2024. Hal ini sesuai dengan tujuan yang tersirat dalam UU no 33 tahun 2014 tentang jaminan produk halal di Indonesia. Selain itu kegiatan ini dapat meningkatkan nilai jual produk kopi bahkan pendapatan bagi masyarakat terutama masyarakat di Desa Baru Manis Kecamatan Bermani Ulu Kabupaten Rejang Lebong. Pengetahuan ini diharapkan dapat disebarluaskan dan diterapkan oleh masyarakat disekitarnya.

\section{KESIMPULAN}

Pelaksanaan kegiatan pengabdian pada masyarakat di Desa Baru Manis Kecamatan Bermani Ulu Kabupaten
Rejang Lebong telah berjalan dengan lancar. Masyarakat petani kopi sudah memahami persyaratan dan kriteria agar produk kopi mereka bisa disebut sebagai produk halal. Kegiatan ini dapat membantu program pemerintah dalam meningkatkan jumlah produk dengan sertifikat halal di Indonesia dan meningkatkan kesadaran masyarakat akan kehalalan suatu produk. Kegiatan ini dapat berjalan dengan bantuan pendanaan dari LPPM Universitas Bengkulu tahun 2020 dengan kontrak No. 2357/UN30.15/AM/2020.

\section{DAFTAR PUSTAKA}

Charity, M.L. 2017. Jaminan Produk Halal di Indonesia. Jurnal Legislasi Indonesia. Vol. 14 No. 01 .

Faridah, H.D. 2019. Sertifikasi Halal di Indonesia : Sejarah, Perkembangan, dan Implementasi. Journal of Halal Product and Research. Vol. 2 No. 2 Hal. 6878.

Huda, N. dan Nazirwan. 2018. Pengembangan Kelompok Usaha Mandiri Masyarakat (KUMM) Menuju Koperasi Syariah. Jurnal Al-Ikhlas. Vol. 3 No. 2. Hal. 133 134

Kardoyo, Muhsin, Fachrurrozie dan Ahmad, N. 2018. IbM Bagi Santri di Kecamatan Gunungpati Kota Semarang Untuk Meningkatkan Minat Berwirausaha. Jurnal AlIkhlas. Vol. 4 No. 1. Hal 58 
Notoatmodjo, S. 2010. Ilmu Perilaku Kesehatan. Jakarta. PT. Rhineka Cipta

Sagala, S. 2009. Konsep dan Makna Pembelajaran untuk Memecahkan Problematika Belajar dan Mengajar. Bandung. Alfaveta.

Triawan, D.A., Charles, B., Morina, A., dan Ria, N. 2021. Pembuatan Asap Cair dari Biomassa Kulit Kopi pada Kelompok Tani Pangestu Rakyat Kabupaten Rejang Lebong. Jurnal Al-Ikhlas. Vol. 6 No. 3. Hal 345

http://www.halal.go.id/layanan/sertifika si (29 maret 2020)

http://www.halalmui.org/mui14/main/de tail/sejarah-perundang-undangan- pelayanan-sertifikasi-halal-diindonesia (29 maret 2020)

https://pakaroti.com/post/trendupdate/latest-trend/pentingnyakehalalan-pada-sebuah-produk (akses 29 maret 2020)

Peraturan Pemerintah no. 31 tahun 2019, tentang Peraturan Pelaksanaan UU no. 33 tahun 2014

Undang-undang no. 33 2014, tentang Jaminan Produk Halal

Warto dan Syamsuri. 2020. Sertifikasi Halal dan Implikasinya bagi Bisnis Produk Halal di Indonesia. Journal of Islamic Economics and Banking. Vol. 2 No. 1 hal. 98-112 